\title{
WHERE THEY LIVED
}

Dishevelled leaves creep down

Upon that bank to-day,

Some green, some yellow, and some pale brown;

The wet bents bob and sway;

The once warm slippery turf is sodden

Where we laughingly sat or lay.

The summerhouse is gone,

Leaving a weedy space;

The bushes that veiled it once have grown

Gaunt trees that interlace, Through whose lank limbs I see too clearly

The nakedness of the place.

And where were hills of blue,

Blind drifts of vapour blow, And the names of former dwellers few,

If any, people know,

And instead of a voice that called, 'Come in, Dears.'

Time calls, 'Pass below!' 